\title{
Morphology of Adrenal Gland and Lymph Organs is Impaired in Neurodeficient Lurcher Mutant Mice
}

\author{
M. BERANOVÁ ${ }^{1}$, P. MANĎÁKOVÁ2 ${ }^{2}$ P. ŠÍMA ${ }^{2}$, J. SLÍPKA ${ }^{1}$, F. VOŽEH ${ }^{3}$, \\ J. KOČOVÁ ${ }^{1}$, M. ČERVINKOVÁ ${ }^{2}$ J. SYYKORA ${ }^{4}$
}

Department of Histology and Embryology, Faculty of Medicine, Charles University, Plzeň, Department of Immunology and Gnotobiology, Institute of Microbiology, Academy of Sciences, Prague, Department of

Pathophysiology, Faculty of Medicine, Charles University, Plzeñ ${ }^{3}$, Department of Pathology, University of Heidelberg, Germany ${ }^{4}$

Received March 14, 2001

Accepted February, 13, 2002

\section{Abstract}

Beranová M., P. Mand'áková, P. Šíma, J. Slípka, F. Vožeh, J. Kočová, M. Červinková, J. Sýkora: Morphology of Adrenal Gland and Lymph Organs is Impaired in Neurodeficient Lurcher Mutant Mice. Acta Vet. Brno 2002, 71: 23-28.

There is a tight structural relation and functional co-operation between the nervous, endocrine and immune systems. A dense network of soluble neuro-endocrine and immune mediators exists to ensure close interactions. These hormones, cytokines and neurotransmitters all interact through positive and negative feed-forward and feedback loops. The mediators, once considered specific to the central nervous system (CNS), the endocrine system (ES) or the immune system (IS), do in fact act in all three systems, forming that way the united neuro-endocrine-immune system. The complex neuro-endocrine-immune networks operate under both physiological and pathological conditions.

In the presented study microscopical analyses of selected immune organs (the thymus, spleen, inguinal and subscapular lymph nodes) and of the adrenal gland of the neurodeficient Lurcher mutant mice and control $\mathrm{C} 3 \mathrm{H}$ mice were performed. In the neurodeficient mice the morphology of the immune organs was impaired. The changes followed in the spleen, especially the increased number of megakaryocytes, lead to the hypothesis of enhanced extramedullar hemopoiesis in the neurodeficient Lurcher mutant mice. Histopathological analysis of the adrenal gland showed the relative hypertrophy of the adrenal medulla. Regarding the adrenal cortex, the three cortical zones, zona glomerularis, fasciculata and reticularis, are difficult to be distinguished. It has been supposed that structural changes of adrenal medulla could document the increased secretion of catecholamines in the neurodeficient animals.

Our observations confirm the idea of the tight cooperation of neuro-endocrine-immune structures and contribute to its better understanding, specifically in the conditions of postnatally progressing neurodeficiency.

Lurcher mutant mice, homeostatic relatioships, neuro-endocrine-immune system, adrenal gland, megakaryocytes

The intrinsic condition for the individual survival is a balance of the internal enviroment homeostasis. There are many proofs of the existence of a unified neuro-endocrine-immune regulatory system that is responsible for maintaining the homeostasis (Michael and Chapman 1990; Weigent and Blalock 1995; Besedovsky et al. 1983). The regulatory relations within that system are mutual and complex (Jankovic 1989; Csaba 1994; Šíma and Větvička 1990; Provinciali and Fabris 1991; Pertseva 1991; Slípka 1961).

To contribute to the explanation of these relations we used in our previous study "an experiment of the nature", gross-brain malformation - anencephaly - which eliminates the central nervous system and consequently the neuro-endocrine part of the homeostatic system (Slípka et al. 1997; B eranová 1994). The spontaneously aborted human foetuses without any external malformation and human anencephalic foetuses were compared with

Address for correspondence:

M. Beranová, Dept. of Histology and Embryology

Faculty of Medicine, Charles University

Czech Republic

Phone: +420 197597227

E-mail: beranovam@fnplzen.cz

http://www.vfu.cz/acta-vet/actavet.htm 
the aim to elucidate the neuro-endocrine-immune interrelationships during ontogeny. In the human anencephalic foetuses with a heavily damaged brain and absence of pituitary gland, the adrenals, the thyroid but also the thymus had been structurally maldeveloped. In seven foetuses with no external malformations the primary adrenal gland atrophy was found in four cases, in which, to the contrary to anencephalic foetuses, no structural changes of other endocrines and thymus have been observed.

To continue and progress in elucidation and morphological description of the neuroendocrine-immune interrelationships we decided to use for our current study an animal model of neurodeficiency, Lurcher mice. These mice are characterized by genetically determined, perinatal severe degeneration of Purkinje, olivary and granule neurons caused by the $\delta 2$ glutamate receptor gene mutation. Lurchers - autosomal heterozygote mutants ( $\mathrm{Lc} /+)$ - suffer by massive decay of the Purkinje cells that causes defects in cognitive and motor functions, presented most often by typical ataxia (Caddy and Vožeh 1997; Vožeh et al. 1998).

In a similar way like some other mutant mice with hereditary cerebellar disorder, e.g. the staggerer mice, the Lurcher mutants display certain abnormalities in endocrine and immune functions. They exhibit an enhanced adrenocorticotropic hormone (ACTH) and corticosterone response to novel enviromental stress and endotoxin (Frederic et al. 1997) and also an abnormal production of some proinflammatory cytokines that modulate immune as well as endocrine functions (Bakalian et al.1992; Kopmels et al. 1990).

It has to be taken into consideration that inherited diseases are frequently characterized by pattern of multiple disorders. These patterns suggest developmental relationship between affected functions or organs and raise the question of whether a given mutation affects the development of different systems independently or if a defect in one system causes dysfunction in others.

The present study aims to contribute to the description of the morphological basis of the neuroendocrine-immune interrelationships that have already been partially discovered from the functional point of view (Kopmels et al. 1991; Bakalian et al. 1992; Frederic et al.1997).

\section{Materials and Methods}

We studied the Lurcher mutant mice in comparison with their healthy littermates - wild type $\mathrm{C} 3 \mathrm{H}$ mice. The Lurcher mice were identified by their ataxic behaviour during their postnatal life. Twenty-five 3-month-old female Lurcher autosomal heterozygote mutants $(\mathrm{Lc} /+)$ and twenty-five age-matched $\mathrm{C} 3 \mathrm{H}$ healthy control individuals were sacrificed by cervical dislocation.

The cerebelar, adrenal, thymic, splenic and lymphatic inguinal and subscapular nodes samples were dissected. Their fixation was performed by $4 \%$ paraformaldehyde and for embedding paraplast (Sigma St. Louis, USA) was used.

Two basic histological staining methods, the modified trichrom staining (Kočová 1970) and hematoxylineosin staining were conveniently used for basic histopathological analysis. To follow the changes of the chromaffin cells in the medulla of the adrenal gland, the chromafin cells specific staining was used. The CD3 receptors were visualised using immunohistochemistry.

The samples were analysed in the light microscope, in certain cases by counting the number of cells by planimetry.

All animals were maintained and all experiments were performed in strict compliance with the revelant rules and animal welfare guideline of the Czech Republic.

\section{Results}

Histological structure of the spleen of the Lurcher mutant mice revealed increased number of megakaryocytes and enlarged white pulp region (Plate I, Fig. 1). Megakaryocytes were situated through the whole parenchyma with maximum occurrence in the close vicinity of the connective tissue trabecules and capsule. The above described morphological features document most probably the enhanced extramedullar hematopoiesis. In the control $\mathrm{C} 3 \mathrm{H}$ mice only rare megakaryocytes were found. They were present only in the close vicinity of the connective tissue capsule (Plate I, Fig. 2). 
The histopathological analyses of the adrenal gland of the neurodeficient mice showed a substantial hypertrophy of cellular medullar elements. All cortical layers, zona glomerulosa, zona fasciculata and zona reticularis were reduced in size. The ratios of these cortical zones did not mutually change, however their borders were diminished (Plate II, Fig. 3). Hypertrophy of the adrenal medulla led to significant increase in the relative ratio medulla/cortex ratio. In the control $\mathrm{C} 3 \mathrm{H}$ mice the adrenal cortical layers were distinguishable and the medullary elements were present (Plate II, Fig. 4).

The morphological analyses of the lymphatic nodules revealed empty paracortical sinuses. The cortex of the nodules also lacked regular follicles. Rarely present follicle-like structures did not contain any folicular germ centers. Lymphocytes were accumulated mainly in the medulla of the nodules, in close vicinity of medullary vascular elements. All these features document the hyporeactivity of the nodule and raise the hypothesis of complex immunodeficiency of the Lurcher mutant mice.

The histopathological examination of the Lurcher mutant mice thymus revealed presence of increased number of Hassal's bodies in the medulla of the thymus. In some sections Hassal's bodies spread even in the thymical cortex. The border between the cortex and the medulla was diminished which was confirmed not only using the basic histological staining techniques but mainly using the CD3 immunohistochemical visualisation. These morphological features suggest that the thymus of the neurodeficient Lurcher mutant mice is affected by dysplasia also called "accidental involution".

\section{Discussion}

Several mutations in mice produce complex patterns of neuronal degeneration of the cerebellum and of its afferent pathways. In some of them, e.g. in the Lurcher mutant mice and in the staggerer ( $\mathrm{sg} / \mathrm{sg}$ ) mutants, atrophy of the lymphoid organs and immunological abnormalities have been described. During the search for a possible link between the neurological and the immune disorders in these mutants, the hyperproduction by its peripheral macrophages of interleukin-1 (IL-1), which roles in both immune and nervous systems was established (Heintz and Zoghbi 2000).

A similar "IL-1 phenomenon" like in Lurchers and staggerers exists in Purkinje cell degeneration (pcd) mutants and to a lesser extent in reeler and wobbler mice, but was absent in the neurological mutants weaver, jimpy, and motor end plate disease (medH) (Kopmels et al. 1990). The above mentioned studies lead us to the hypothesis that the neuronal degeneration affecting the cerebellum in different mutant mice do not lead to the same immunological defect at the peripheral level.

Lurcher mutant mice are characterized by genetically determined, perinatal severe degeneration of Purkinje, olivary and granule neurons caused by the 2 glutamate receptor gene mutation. Glutamate receptors (GluRs) are ubiquitously present in the central nervous system (CNS) as the major mediators of excitatory neurotransmission and excitotoxicity. Neural injury associated with trauma, stroke, epilepsy, and many neurodegenerative diseases such as Alzheimer's, Huntington's, and Parkinson's diseases and amyotrophic lateral sclerosis may be mediated by excessive activation of GluRs. Neurotoxicity associated with excitatory amino acids encountered in food, such as domoic acid and monosodium glutamate, has also been linked to GluRs. Less is known about GluRs outside the CNS. Recent observations suggest that several subtypes of GluRs are widely distributed in peripheral tissues. Using immunochemical and molecular techniques, the presence of GluR subtypes are also present in kidney, liver, lung, spleen, and testis (Gill et al. 2000). The histological structure of the Lurcher mutant mice spleen revealed increase of number of megakaryocytes and enlarged white pulp region that corresponds to enhanced extramedullar hematopoiesis.

The hematopoiesis is a complex mechanism that can be influenced not only by immune 
system stimuli but also by variety of different neurotransmitters and neuromodulators. It was described that huntingtin, widely expressed protein associated with Huntington's neurodegenerative disease, can also be detected in spleen and thymus. It was hypothetised that it also plays a crucial role in hematopoiesis as long as huntingtin expression is required for the generation and expansion of hematopoietic cells (Metzler et al. 2000).

The thymic dysplasia also called "accidental involution" (Muller-Hermelink 1986; Bargmann 1943) that we describe in Lurcher mutant mice was already documented in few other models of neurodeficiency. As we described previously, anencephalic foetuses posses heavily malformed brain frequently without present pituitary (Slípka et al. 1997) followed by multiple endocrine disorders (hypoplastic or even aplastic endocrine organs) and the thymus dysplasia sometimes called accidental involution. A similar picture can also be seen in another neurodeficient animal model, in jumonji mice. A novel gene, called jumonji gene was identified by a mouse gene trap strategy during the recent search for the genetic backgrounds of control of the hematopoiesis (Takeuchi et al. 1999). This jumonji gene encodes a protein containing a putative DNA binding domain. The mice homozygous for jumonji gene mutation with a $\mathrm{BALB} / \mathrm{cA}$ or $\mathrm{C} 3 \mathrm{H}$ genetic background show hypoplasia of the fetal liver and embryonic lethality, suggesting impaired hematopoiesis. Definitive but not primitive hematopoiesis is impaired in jumonji mutant mice (Kitaji ma et al. 1999). Some, but not all, of the homozygotes jumonji develop an abnormal groove in a region just anterior to the midbrain-hindbrain boundary on the neural plate at embryonic day 8-8.5 and show a defect in neural tube closure in the midbrain region which proves that this gene is also required for the neural tube formation (Takeuchi et al. 1995). As long as these mutants also suffer from the hypoplasia of the liver, thymus and spleen, it can be suggested that the jmj gene plays an essential role also in the organogenesis of these tissues (Motoyama et al. 1997). This could actually be one of the genes playing crucial role in neuro-endocrine-immune interrelationships.

Morphological findings confirming the close interrelationship between the nervous and immune system and the hematopoiesis were described not only in mice but also in many other different species, e.g. hedgehogs. Postmortem examination of 14 hedgehogs (Erinaceus europaeus) affected by paraplegia revealed demyelination in the brain and spinal cord and an inflammatory response in the meninges, choroid plexus and CNS. In the spleen, lungs and liver there was an accumulation of megakaryocytes and other evidence of extramedullary haemopoiesis (Palmer et al. 1998).

The adrenal gland combines two endocrine tissues of diverse embryogenetic origin under a common capsule. It undergoes dynamic structural changes under physiological and pathological conditions (Wolkersdorfer and Bornstein 1998; Bornstein et al. 1994). Those dynamic changes are covered by cell proliferation as well as cell death. Hormonal, paracrine and intracellular signals initiate the processes required for these phenomenona. The histopathological analyses of the adrenal gland of the neurodeficient mice showed a significant hypertrophy of cellular medullar elements. The size of cortical zones was reduced proportionally however the ratios of all three cortical zones did not mutually change. The hypertrophy of the adrenal medulla led to significant increase in the relative ratio medulla/cortex ratio. The relative hypertrophy of the adrenal medulla responds to the increased secretion of catecholamines in the neurodeficient animals. The described morphological changes correspond to the dynamic hormonal changes described in Lurchers previously (Frederic et al. 1997).

The histologic examinations of the adrenal glands of Lurcher mutant mice revealed certain morphological similarities to the adrenal glands of the human anencephalic fetuses. The anencephalics had also greater amounts of medullary tissue than controls, the cells of the adrenal medulla of the anecephalic fetusus showed progressive maturation during fetal life from neuroblastic cells to larger cells with increased cytoplasm, to still larger cells with 
vacuolated cytoplasm and a positive chromaffin reaction (Bocian-Sobkowska et al. 1997; Namnoum et al. 1990; Young et al. 1989).

Work is in progress to establish whether the described morphological abnormalities result from a defect intrinsic to the organs of the mutant mice or are secondary to the degenerative process ultimately leading to neuronal loss. From the results presented we hypothetised that the structural alterations caused by neurodegeneration may elicit non-reversible changes in both morphology and funtion of all organs involved in the homeostatic control of an organism. Our histological comparative analysis of primary imunocompetent organ thymus, secondary immunocompetent organs - spleen and inguinal and subscapular lymph nodes, and adrenal glands confirms the widely accepted idea about the cooperation between the immune and neuro-endocrine regulation.

Further investigations are needed to assess the role of glutamate receptors in peripheral tissues and their contribution to the neuro-endocrine-immune relatioships.

\section{Změny morphologie nadledviny a lymfatických orgánů u neurodefektních Lurcherských mutantních myší}

Nervový, endokrinní a imunitní systém jsou vzájemně propojeny jak mnohými strukturami, tak vzájemnými funkčními vztahy. Bohatá sít rozpustných neuro-endokrinních a imunitních mediátorů zabezpečuje možnost interakcí. Tyto hormony, cytokiny a neurotransmittery jsou regulovány na základě pozitivních a negativních "feed-forward" a "feed-back" vztahů. Mediátory, jež byly původně považovány za specifické pro centrální nervový systém (CNS), endokrinní systém (ES) nebo imunnitní systém (IS), ve skutečnosti působí ve všech výše zmíněných systémech, tvoříc tak jeden integrovaný neuro-endocrinoimunnitní systém. Komplexní neuro-endokrino-imunitní sít pracuje jak za fyziologických, tak za patologických podmínek.

V této práci presentujeme výsledky histopatologických analýz vybraných imunitních orgánů (thymu, sleziny, inquinálních a subskapulárních lymfatických uzlin) a nadledvin neurodefektních Lurcherských mutantních myší a kontrolních C3H myší. U neurodefektních myší byla morfologie imunitních orgánů postižena. Změny ve struktuře sleziny, zvláště pak zvýšený počet megakaryocytů, vedou $\mathrm{k}$ hypothéze zvýšené extramedulární hemopoesy u neurodefektních Lurcherských mutantních myší. Morfologie nadledvin vykazovala relativní hypertrofii v dřeňové části. Struktura jednotlivých vrstev kůry nadledvin, zony glomerularis, fasciculata a reticularis, je setřelá. Předpokládáme, že strukturální změny adrenální dřeně dokumentují zvýšenou sekreci katecholaminů u neurodefektních zvířat.

Naše pozorování potvrzují ideu těsné kooperace neuro-endokrino-imunnitních struktur a přizpívají $\mathrm{k}$ jejímu porozumění, zvláště pak $\mathrm{v}$ podmínkách postnatálně progredující neurodeficience.

\section{Acknowledgements}

The study was supported by the grant GA AV ČR 98/ reg. No. A 7020809.

\section{References}

BAKALIAN, A., KOPMELS, B., MESSER, A., FRADELIZI, D., DELHAYE-BOUCHAUD, N., WOLLMAN, E., MARIANI, J. 1992: Peripheral macrophage abnormalities in mutant mice with spinocerebellar degeneration. Res Immunol. 143:129-39

BARGMANN, W. 1943: Der Thymus. In:Handbuch der mikroskopischen Anatomie des Menschen. Mollendorf, W.(Red.), Bd.VI., Teil IV., pp:1-172

BERANOVÁ, M. 1994: Anencephaly and the adrenal gland. J. Eur. Med. Stud. Assoc. 3: 20-21

BESEDOVSKY, H. O., DEL REY, A.E., SORKIN, E. 1983: What do the immune system and brain know about each other? Immunology Today 12: 342-346

BOCIAN-SOBKOWSKA, J., MALENDOWICZ, L. K., WOZNIAK, W. 1997: Comparative stereological study 
on zonation and cellular composition of adrenal glands of normal and anencephalic human fetuses. I. Zonation of the gland. Histol Histopathol. 12: 311-317

BOCIAN-SOBKOWSKA, J., MALENDOWICZ, L.K., WOZNIAK, W. 1997: Comparative stereological studies on zonation and cellular composition of adrenal glands of normal and anencephalic human fetuses. II. Cellular composition of the gland. Histol Histopathol. 12: 391-399

BORNSTEIN, S. R., GONZALES-HERNANDEZ, J. A., EHRHART-BORNSTEIN, M., ADLER, G., SCHERBAUM, W. A. 1994: Intimate contact of chromaffin and cortical cells within the human adrenal gland forms the cellular basis for important intraadrenal interactions. JCEM. 78. 1: 225-232

CADDY, K.W., VOŽEH, F. 1997: The effect of 3-acetylpyridine on inferior olivary neuron degeneration in Lurcher mutant and wild-type mice. Eur. J. Pharmacol. 330: 139-42

CSABA, G. 1994: Phylogeny and ontogeny of chemical signaling: Origin and development of hormone receptors. Internat. Rev. Cytol. 155: 1-48

FREDERIC, F., CHAUTARD, T., BROCHARD, R., CHIANALE, C., WOLlMAN, E., OLIVER, C., DELHAYE-BOUCHAUD, N., MARIANI, J. 1997: Enhanced endocrine response to novel environment stress and endotoxin in Lurcher mutant mice. Neuroendocrinology 66: 341-347

GILL, S. S., MUELLER, R. W., MCGUIRE, P. F., PULIDO, O. M. 2000: Potential target sites in peripheral tissues for excitatory neurotransmission and excitotoxicity. Toxicol Pathol. 28: 277-284

HEINTZ, N., ZOGHBI, H. Y. 2000: Insights from mouse models into the molecular basis of neurodegeneration. Annu Rev Physiol. 62: 779-802

JANKOVIC, B. D.1989: Neuroimmunomodulation: facts and dilemas.Immunology Lettters 21: 101-118

KITAJIMA, K., KOJIMA, M., NAKAJIMA, K., KONDO, S., HARA, T., MIYAJIMA, A., TAKEUCHI, T. 1999: Definitive but not primitive hematopoiesis is impaired in jumonji mutant mice. Blood 93: 87-95

KOČOVÁ, J. 1970: Overall staining of connective tissue and the muscular layer of vessels. Folia Morphol (Praha) 18: $293-295$

KOPMELS, B., WOLlMan, E.E., GUASTAVINO, J.M., DELHAYE-BOUCHAUD, N., FRADELIZI, D., MARIANI, J. 1990: Interleukin-1 hyperproduction by in vitro activated peripheral macrophages from cerebellar mutant mice. J Neurochem. 55: 1980-1985

KOPMELS, B., MARIANI, J., TAUPIN, V., DELHAYE-BOUCHAUD, N., WOLLMAN, E.E. 1991: Differential IL-6 mRNA expression by stimulated peripheral macrophages of Staggerer and Lurcher cerebellar mutant mice. Eur Cytokine Netw. 2: 345-353

METZLER, M., HELGASON, C. D., DRAGATSIS, I., ZHANG, T., GAN, L., PINEAULT, N., ZEITLIN, S. O., HUMPHRIES, R. K., HAYDEN, M. R. 2000: Huntingtin is required for normal hematopoiesis. Hum. Mol. Genet. 12; 9: 387-394

MICHAEL, S. D., CHAPMAN, J. C. 1990: The influence of endocrine system on the immune system. Immun. et Allergy Clin. North America 10: 215-233

MOTOYAMA, J., KITAJIMA, K., KOJIMA, M., KONDO, S., TAKEUCHI, T. 1997: Organogenesis of the liver, thymus and spleen is affected in jumonji mutant mice. Mech Dev. 66: 27-37

MULLER-HERMELINK, H. K. 1986. The Human Thymus. Springer Verlag. Berlin.

NAMNOUM, A. B., HUTCHINS, G. M. 1990: Accelerated maturation of the adrenal medulla in anencephaly. Pediatr Pathol. 10: $895-900$

PALMER, A. C., BLAKEMORE, W. F., FRANKLIN, R. J., FROST, L. M., GOUGH, R. E., LEWIS, J. C. MACDOUGALL, D. F., O'LEARY, M. T., STOCKER, L. R. 1998: Paralysis in hedgehogs (Erinaceus europaeus) associated with demyelination. Vet. Rec. $143: 550-552$

PERTSEVA, M. 1991: The evolution of hormonal signalling systems. Comp. Biochem. Physiol. 100: 775-787

PROVINCIALI, M., FABRIS, N. 1991. Models and mechanisms of neuroendocrine-immune interactions during ontogeny. Adv. Neuroimmun. 1: 124-138

ŠÍMA, P., VĚTVIČKA, V. 1990: Evolution of immune reactions. CRC Press, Inc. Boca Raton

SLÍPKA, J., BERANOVÁ, M., ŚÍMA, P.: Gross brain malformation in relation to the development of immune and endocrine system. Biogenic Amines 13: 379-384

SLÍPKA, J. 1992: The development of the palatine tonsils in germ-free piglets. Verh. Anat. Ges. Suppl. 174: 143

TAKEUCHI, T., KOJIMA, M., NAKAJIMA, K., KONDO, S. 1999: Jumonji gene is essential for the neurulation and cardiac development of mouse embryos with a C3H/He background. Mech Dev. 86: 29-38

TAKEUCHI, T., YAMAZAKI, Y., KATOH-FUKUI, Y., TSUCHIYA, R., KONDO, S., MOTOYAMA, J., HIGASHINAKAGAWA, T. 1995: Gene trap capture of a novel mouse gene, jumonji, required for neural tube formation. Genes Dev. 9; 15: 1211-22

VOŽEH, F., CADDY, K. W., MYSLIVEČEK, J. 1998: Morphologic and functional characteristics of an animal model of cerebellar degeneration. Čs. Fysiol. 47: 74-79

WEIGENT, D. A., BLALOCK, J. E. 1995: Associations between the neuroendocrine and immune system. J. Leukoc. Biol. 57: 137-150

WOLKERSDORFER, G. W., BORNSTEIN, S. R. 1998: Tissue remodeling in the adrenal gland. Biochemical Pharmacology 56: 163-171

YOUNG, M. C., LAURENCE, K. M., HUGHES, I. A. 1989. Relationship between fetal adrenal morphology and anterior pituitary function. Horm. Res. 32:130-135 
Plate I

Beranová M. et al.: Morphology... pp. 23-28

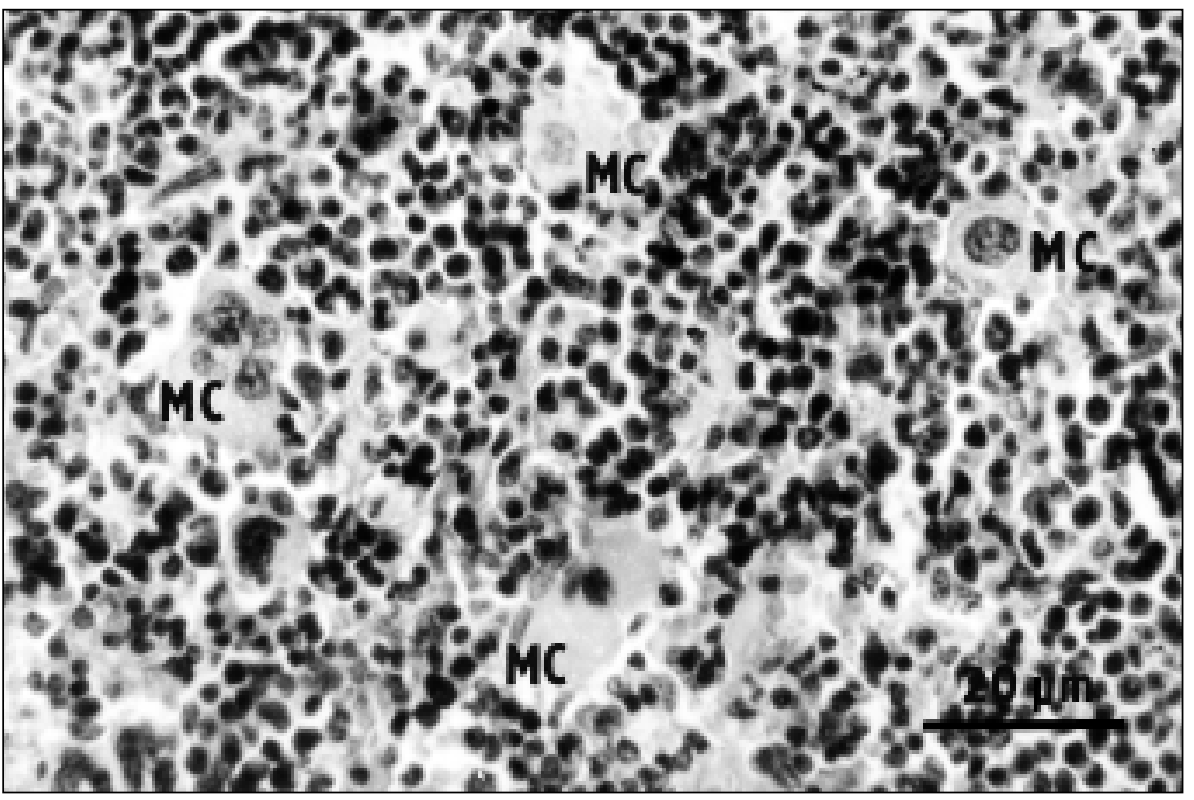

Fig. 1. The spleen of Lurcher mutant mice (female): abundant megakaryocytes (MC) spread in the whole parenchyme, direct magnification: $\times 63$

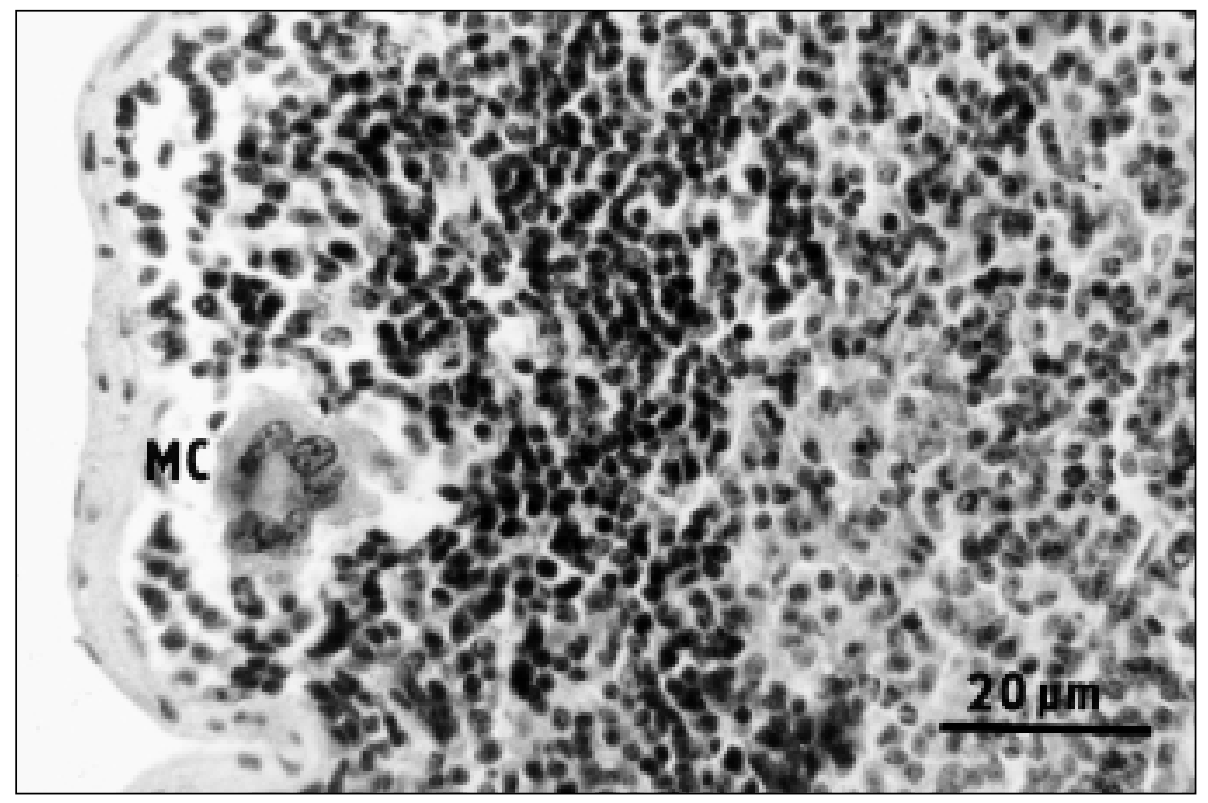

Fig. 2. The spleen of $\mathrm{C} 3 \mathrm{H}$ control mice (female): rare magakaryocytes (MC), present only in the close vicinity of the connective tissue capsule, direct magnification: $\times 63$ 


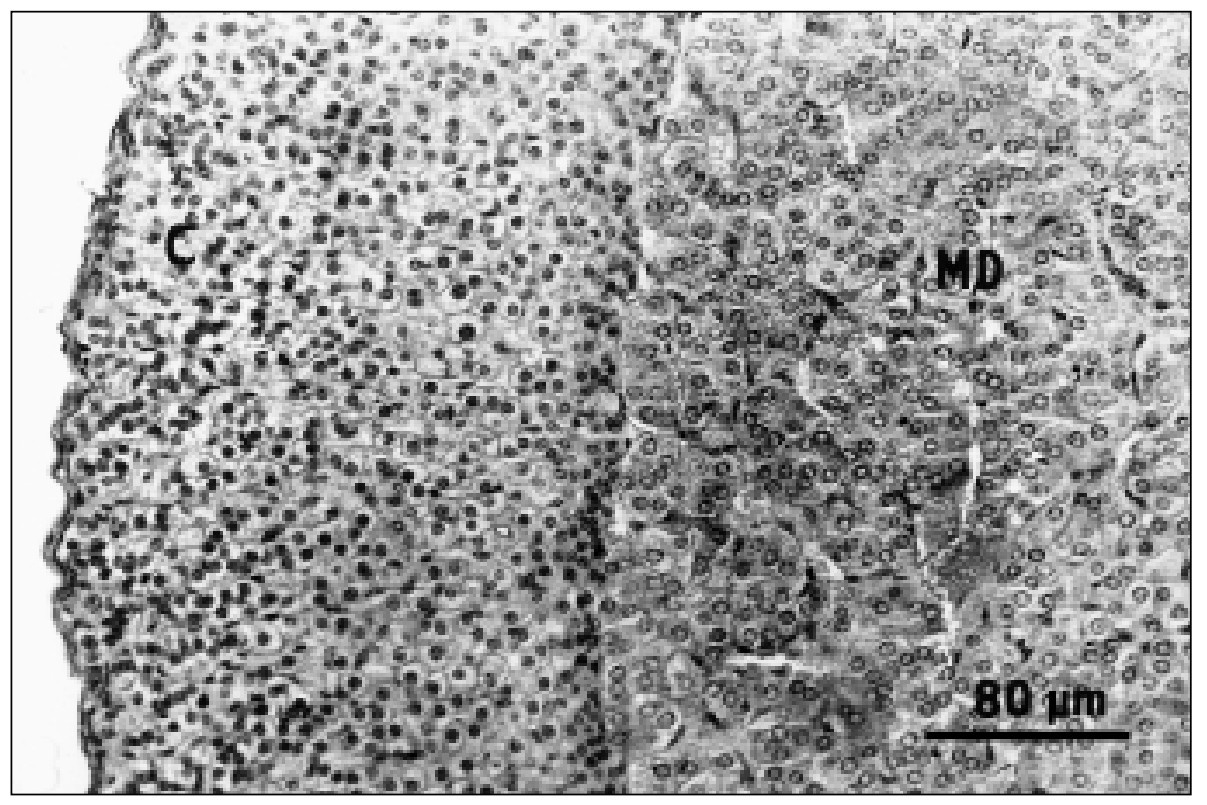

Fig. 3. The adrenal gland of Lurcher mutant mice (female): significant hyperplasia of the medulla (MD) hypoplasia and dedifferenciation of cortex $(\mathrm{C})$ and its layers ( zona glomerulosa $-\mathrm{ZG}$, zona fasciculata $\mathrm{ZF}$, zona reticularis $-\mathrm{ZR}$ ), direct magnification: $\times 25$

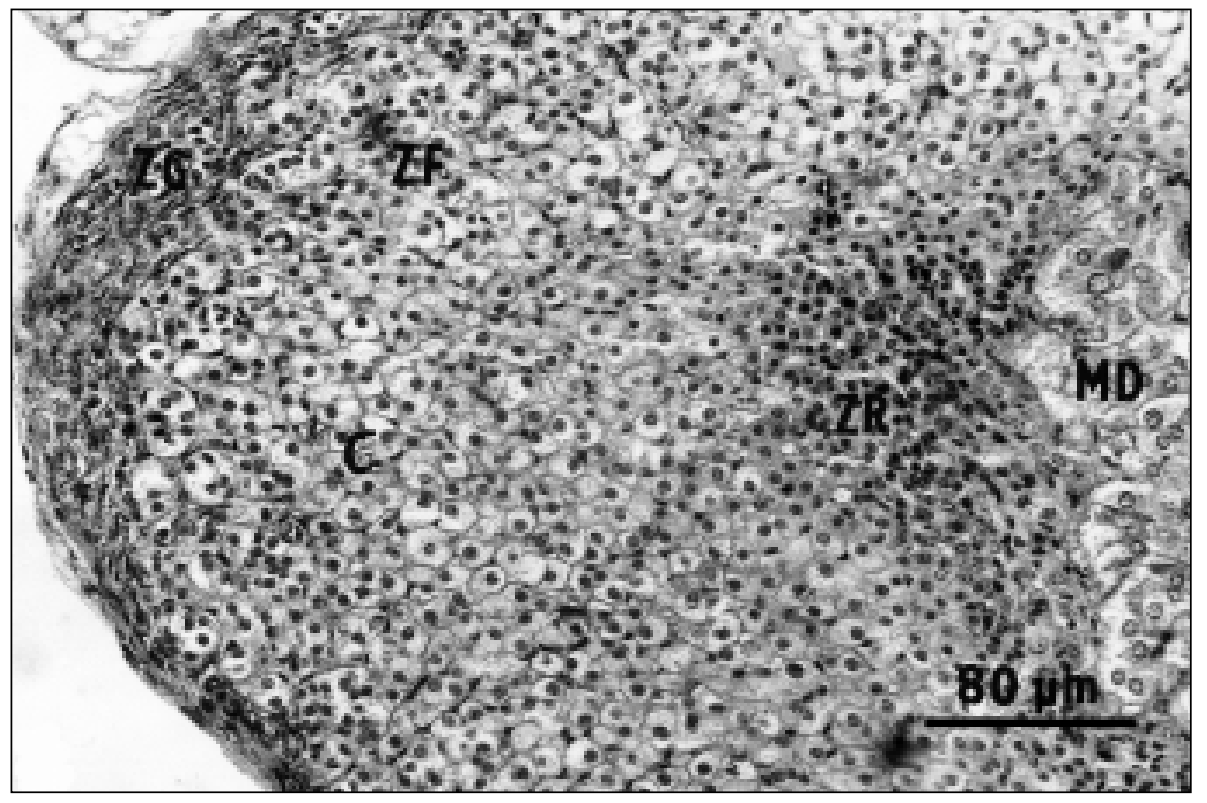

Fig. 4. The adrenal gland of $\mathrm{C} 3 \mathrm{H}$ control mice (female): cortex (C) with all layers distinguishable - zona glomerulosa $-\mathrm{ZG}$, zona fasciculata $-\mathrm{ZF}$ and zona reticularis $-\mathrm{ZR}-$ medulla (MD) present, direct magnification: $\times 25$ 